\title{
EFFECT OF SEMINAR ON THE PARENTAL ROLE IN REPRODUCTIVE HEALTH COMMUNICATION WITH ADOLESCENTS IN CIREBON, WEST JAVA
}

\author{
Yeni Fitrianingsih and Diyah Sri Yuhandini
}

\author{
Study Program of Midwifery, School of Health Polytechnics, \\ Ministry of Health, Tasikmalaya
}

\begin{abstract}
Background: The reasons of adolescents engage in sexual activity are diverse. Several interventions to promote sexual and reproductive health have been developed and implemented, mainly targeting school-going young people. Due to the consequences of the sexual disease pandemic, parents are making attempts to communicate with their children about reproductive health. This study aimed to determine the effect of seminar on the parental role in reproductive health communication with adolescents in Cirebon, West Java.

Subjects and Method: This was a quasi-experiment with pre and posttest group design conducted in Cirebon, West Java. A sample of 60 students was selected by simple random sampling. The dependent variable was reproductive health communication. The independent variable was seminar on the parental role. The data was collected by questionnaire and analyzed by t test.

Results: Knowledge of reproductive health among the adolescents was higher after the intervention than before the intervention, and it was statistically significant.

Conclusion: Seminar on the parental role is effective to enhace reproductive health communication for adolescents.
\end{abstract}

Keywords: parental role, reproductive health communication, adolescents

\section{Correspondence:}

Yeni Fitrianingsih. Study Program of Midwifery, Study Program of Midwifery, School of Health Polytechnics, Ministry of Health, Tasikmalaya, West Java.

Email: yfitrianingsih44@gmail.com. Mobile: 082116122264.

The 5th International Conference on Public Health

Best Western Premier Hotel, Solo, Indonesia, February 13-14, $2019 \mid 183$

https://doi.org/10.26911/theicph.2019.02.28 